\title{
Disruption of BMP signals in embryonic Xenopus ectoderm leads to direct neural induction
}

\author{
Stephanie H.B. Hawley, ${ }^{1}$ Katrin Wünnenberg-Stapleton, ${ }^{1}$ Chikara Hashimoto, Micheline N. Laurent, \\ Tetsuro Watabe, Bruce W. Blumberg, ${ }^{2}$ and Ken W.Y. Cho ${ }^{3}$ \\ Developmental Biology Center and the Department of Developmental and Cell Biology, University of California, Irvine, \\ California 92717-2300 USA
}

\begin{abstract}
Bone morphogenetic proteins (BMPs), which have been implicated in the patterning of mesoderm, are members of the transforming growth factor- $\beta$ (TGF- $\beta$ ) superfamily. We have investigated the roles of Xenopus BMP-7 (XBMP-7) and BMP-4 (XBMP-4), and activin (another TGF- $\beta$-related molecule) in early development by generating dominant-negative versions of these growth factors. Mutations were generated by altering the cleavage sites that are required for maturation of the active dimeric forms of XBMP-7, XBMP-4, and activin. These mutant constructs, designated $\mathrm{Cm}-\mathrm{XBMP}-7, \mathrm{Cm}-\mathrm{XBMP}-4$, and $\mathrm{Cm}$-activin, result in polypeptides that allow for dimerization of the subunits, but are incapable of maturation. Expression of Cm-XBMP-7 and Cm-XBMP-4, but not $\mathrm{Cm}$-activin, in the ventral marginal zone of the Xenopus embryo results in the development of a secondary axis, similar to that seen by ectopic expression of the truncated BMP receptor. These results suggest that the cleavage mutants interfere with BMP signaling during mesodermal patterning. We also found that expression of $\mathrm{Cm}-\mathrm{XBMP}-7$ or $\mathrm{Cm}-\mathrm{XBMP}-4$ in animal cap ectoderm directly induces neuroectoderm. The neural induction was specific for $\mathrm{Cm}-\mathrm{XBMP}-7$ and $\mathrm{Cm}-\mathrm{XBMP}-4$ because ectopic expression of $\mathrm{Cm}$-activin or $\mathrm{Vg}-1$ did not mimic the same phenotype. Molecular study of neural patterning by $\mathrm{Cm}-\mathrm{XBMP}-7$ and $\mathrm{Cm}-\mathrm{XBMP}-4$ revealed that only anterior neuroectodermal markers are expressed in response to these $\mathrm{Cm}$-XBMPs. These results suggest that the BMPs are involved in the specification of ectoderm in Xenopus development, and that neural induction requires the removal of BMP signals in the ectoderm. We propose that neural induction occurs by a default mechanism, whereby the inhibition of BMP signaling is required for the conversion of ectoderm to neuroectoderm in the developing Xenopus embryo.
\end{abstract}

[Key Words: BMP-7; BMP-4; activin; dominant negative; TGF- $\beta$; amphibian; cement gland]

Received June 26, 1995; revised version accepted October 13, 1995.

Vertebrate neural induction occurs during gastrulation and involves the respecification of ectoderm to become neuroectoderm, together with the imposition of anterior-posterior pattern (Holtfreter 1933; Mangold 1933). In amphibia, neural induction is thought to occur through the influence of the newly induced Spemann's organizer (dorsal mesoderm) on dorsal ectoderm in a two-step process (Nieuwkoop 1952, 1985). Initially anterior mesoderm (also known as the organizer) induces overlying ectoderm to become anterior neural tissue (e.g., forebrain). This process is then followed by a transformation step, caused by the involuting chordamesoderm, which posteriorizes the ectoderm to form more posterior structures such as hindbrain and spinal cord (Nieuwkoop 1952).

\footnotetext{
${ }^{1}$ These authors contributed equally.

${ }^{2}$ Present address: The Salk Institute, San Diego, California 92138-9216 USA.

${ }^{3}$ Corresponding author.
}

The substances that mediate neural induction are currently under intense investigation. Presently three molecules, noggin, follistatin, and chordin, have been shown to exhibit anterior neural-inducing activity in vitro, and are expressed in prechordal and notochordal mesoderm in vivo during gastrulation (Lamb et al. 1993; HemmatiBrivanlou et al. 1994; Sasai et al. 1995). Noggin is a secreted molecule that can induce anterior neural markers directly in naive gastrula ectoderm without inducing mesoderm. Follistatin inhibits activin [a growth factor belonging to the transforming growth factor (TGF)- $\beta$ superfamily] signaling by physically sequestering activin (Kogawa et al. 1991), and is thought to release activinmediated repression of neural induction. Chordin, a Xenopus homolog of Drosophila short gastrulation (sog), encodes a novel secreted molecule (Francois et al. 1994; Holley et al. 1995) and has been shown to be antagonized by bone morphogenetic protein-4 (BMP-4) (Sasai et al. 1995).

Although the search for the natural neural inducers 
continues, experiments involving dissociation and culturing of uninduced animal cap ectodermal cells have demonstrated that neural fate represents a default state for the ectoderm (Godsave and Slack 1989; Grunz and Tacke 1989). Using a dominant-negative version of the activin receptor, activin has been implicated in this default mechanism of neural induction (Hemmati-Brivanlou and Melton 1994). According to this model, low levels of activin-type molecules are required in the ectoderm to prevent it from becoming neural tissue, and inhibition of activin signaling leads to direct neural induction. A potential criticism of such an activin receptor interference approach is the difficulty in demonstrating that only one signaling pathway is affected. As there exist several activin receptors, as well as other receptors belonging to members of the TGF- $\beta$ superfamily in $X e$ nopus embryos (Kondo et al. 1991; Nishimatsu et al. 1992a; Graff et al. 1994; Suzuki et al. 1994), ectopic expression of a dominant-negative mutant activin receptor may interfere in the signaling of other members of the TGF- $\beta$ superfamily. In support of this view, it has been found that the dominant-negative mutant activin receptor blocks not only activin, but also BVg-1- and BMP-4-mediated signaling (Schulte-Merker et al. 1994; Wilson and Hemmati-Brivanlou 1995), suggesting that the default mechanism of neural induction may involve a non-activin member (or members) of the TGF- $\beta$ superfamily.

Studies on the receptors for TGF- $\beta$-type growth factors have established that transduction of TGF- $\beta$ signals requires two distinct types (type I and type II) of transmembrane serine-threonine kinase receptors (Massagué 1992). The prevailing view suggests that the TGF- $\beta$ ligand binds to the type II receptor, which then recruits a type I receptor. After formation of a ligand-type II-type I ternary complex, the type II receptor phosphorylates the type I receptor. The type I receptor is then able to transmit an intracellular response (Wrana et al. 1994). The formation of heterodimeric complexes between type II and type I receptors raises the interesting point that a given type II receptor may cross-interact with other members of the type I receptor class of the TGF- $\beta$ superfamily. Consistent with this notion, some members of the type II activin receptor group have been shown to interact with the type I receptors for both activin and TGF- $\beta$ I (tenDijke et al. 1994), as well as interacting with BMP type I receptors to bind human OP-1 (BMP-7) (Yamashita et al. 1995). In addition, Drosophila punt, a type II receptor and a mediator of decapentaplegic (dpp) (a BMP-2/BMP-4 homolog) signaling (Letsou et al. 1995), has been shown to specifically bind activin (Childs et al. 1993). The interaction of BMPs with type II activin-like receptors suggests that the observed neural induction by dominant-negative mutant activin receptors may be caused by the inhibition of BMP signaling.

An alternative approach to study the effect of signaling by TGF- $\beta$-related growth factors is to generate dominant-negative growth factors by mutating cleavage sites (Lopez et al. 1992). Molecules belonging to the TGF- $\beta$ superfamily form homodimers or heterodimers by the dimerization of two precursor chains. This is followed by cleavage of the precursor dimers to release a mature protein derived from the carboxyl terminus /Vale et al. 1990). Because cleavage of the precursor dimers at the conserved cleavage site is necessary for the maturation to an active molecule, mutations in the cleavage sites would result in nonfunctional molecules. It has been shown in both TGF- $\beta 1$ and activin that precursors mutated in this conserved cleavage region were not cleaved so as to release an active dimeric protein, and thus, are suggested to function as dominant-negative molecules (Lopez et al. 1992; Wittbrodt and Rosa 1994).

We generated similar cleavage mutants in Xenopus activin as well as BMP-7 and BMP-4 (XBMP-7 and XBMP4), a family of genes that is thought to be important during early Xenopus embryogenesis (Asashima et al. 1990; Thomsen et al. 1990; Dale et al. 1992; Jones et al. 1992; Nishimatsu et al. 1992b). In this report we demonstrate that these cleavage mutants are both effective and specific as dominant-negative ligands, suggesting that this approach should be generally applicable in studying the function of various TGF- $\beta$-related molecules in vivo. Our data suggest that neural induction occurs by an inhibition of BMP signals in the ectoderm. Curiously, a similar assay using an activin cleavage mutant failed to induce neural tissue. Our results are consistent with the notion that neural induction in Xenopus occurs through a default pathway, and we propose that BMP plays a crucial role in repression of this default pathway of neural induction.

\section{Results}

\section{Spatiotemporal expression pattern of XBMP-7}

We isolated cDNAs encoding XBMP-7 (also previously called OP-1; Ozkaynak et al. 1990) during the course of screening for TGF- $\beta$-related molecules in Xenopus gastrula stage embryo libraries. Sequencing analysis revealed that our XBMP-7 cDNA sequences are similar, but not identical, to the previously reported XBMP-7 sequence (Nishimatsu et al. 1992b). In addition to minor substitutional changes, our XBMP-7 cDNA contains an additional $600 \mathrm{bp}$ of $3^{\prime}$-untranslated sequence (EMBL/ GenBank accession no. U38559|. Northern blot analysis of XBMP-7 transcripts using RNA isolated from whole embryos as well as dissected embryonic fragments revealed the presence of abundant maternal transcripts and localized expression of XBMP-7 transcripts in gastrula ectoderm and marginal zone mesoderm, but not in the endoderm (data not shown). By whole mount in situ hybridization, the ectodermal expression of XBMP-7 becomes detectable in blastulae (Fig. 1A), and persists through gastrula stages uniformly in both the mesoderm and the ectoderm (Figure 1B-D). In neurula stages XBMP-7 is enriched in the cement gland anlage (Fig. $1 E, F)$. In the stage 22 embryo, XBMP-7 transcripts are also expressed in the cement gland, heart anlage, proctodeum, and midline of the anterior neuroectoderm (Fig. $1 G, H)$. The early expression patterns of XBMP-7 suggest 

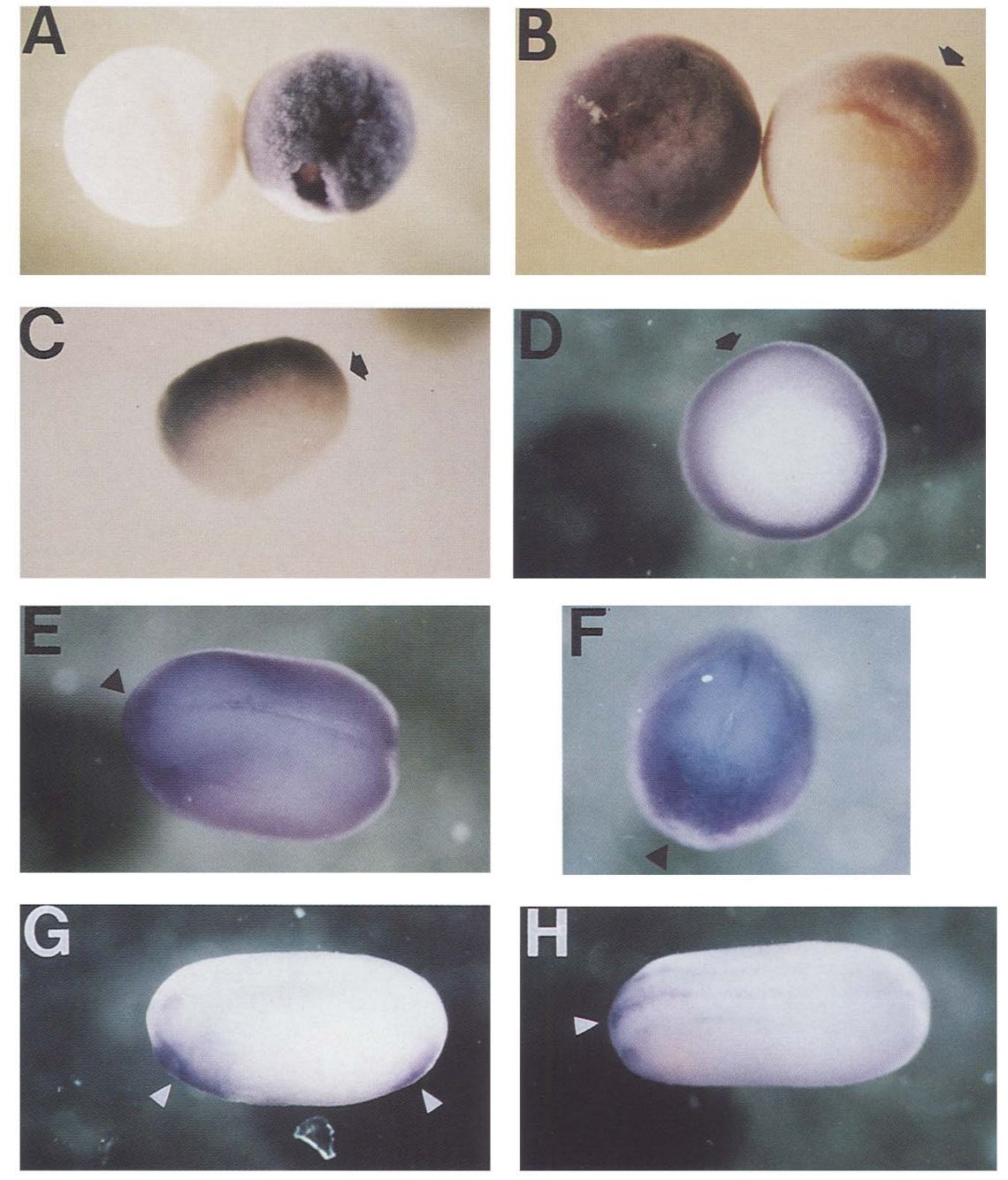

that it plays a major role in ectodermal and mesodermal cell differentiation during embryogenesis.

Although some expression patterns of XBMP-7 are similar to that of XBMP-4, unique aspects of XBMP-7 expression should be noted. First, there are abundant XBMP-7 maternal transcripts present in embryos, but no maternal XBMP-4 transcripts are detectable (Nishimatsu et al. 1992b). Second, although XBMP-7 transcripts are detectable throughout the entire marginal zone mesoderm (Fig. 1B-D), the expression of XBMP-4 is excluded from the organizer region (Fainsod et al. 1994; Schmidt et al. 1995). Interestingly, the expression of XBMP-7 in the organizer is consistent with the expression of mouse BMP7 in the anterior primitive streak and node, a murine organizer equivalent tissue (Lyons et al. 1995).

\section{Generation of dominant-negative XBMP mutants}

The structure of the BMP molecule offers potential target sites for the creation of dominant-negative BMP ligands. Because activation of BMP requires cleavage of the precursor dimers, mutating the conserved cleavage sequences required for activation should result in the synthesis of a nonfunctional BMP polypeptide (Fig. 2A). This has been demonstrated by Wittbrodt and Rosa (1994) for fish activin. The conserved peptide sequences of XBMP-7, XBMP-4, and activin (RSVR, RSKR, and RKKR, respectively) were replaced by GVDG, a modification expected to yield a nonfunctional protein (cleavage mutant; $\mathrm{Cm}$ ). The $\mathrm{Cm}$ proteins are expected to dimerize with and titrate out the native wild-type proteins, thus functioning as dominant-negative ligands.

An in vivo translation assay in Xenopus oocytes was used to study the processing of the cleavage mutants. Figure $2 \mathrm{~B}$ shows that expression of wild-type activin mRNA generated the active $14-\mathrm{kD}$ carboxy-terminal peptide and the $37-\mathrm{kD}$ precursor remainder peptide (lane 2), whereas $\mathrm{Cm}$-activin generated only the $51-\mathrm{kD}$ single polypeptide (lane 3). This indicates that $\mathrm{Cm}$-activin was not cleaved. Expression of wild-type XBMP-7 and XBMP-4 mRNAs in oocytes produced precursor remainder peptides ( 34 and $35 \mathrm{kD}$, respectively), but the active carboxy-terminal peptides of XBMP-7 and XBMP-4 (17 and $13 \mathrm{kD}$, respectively) were not detectable (lanes 4,6 ). 
Figure 2. Expression of synthetic mRNAs after oocyte injection. $(A)$ Schematic representation of wild-type and mutated BMP and activin molecules. The RXXR amino acid cleavage site sequences in the BMP and activin molecules were mutated to GVDG in the cleavage mutant constructs. Native molecules form dimers (the disulfide bond is indicated), which are then cleaved to form the carboxyterminal mature ligand (shaded region) and the amino-terminal precursor remainder peptide (hatched region). The cleavage mutants do not mature; thus, oocytes injected with the cleavage mutant constructs only generate the high molecular weight uncleaved polypeptide. The relative positions of HA and Flag epitopes within the pro-domain are indicated. $(B)$ In vivo translation of wild-type and cleavage $\mathrm{mu}$ tant mRNAs. Media from oocytes injected with 50-200 ng of the indicated mRNAs were pulse labeled ( $3 \mathrm{hrs}$ ) with $\left[{ }^{35} \mathrm{~S}\right)$ methionine and then analyzed by $14 \%$ SDS-PAGE under reducing conditions. Wild-type activin is cleaved to form two polypeptides 137 and 14 $\mathrm{kD}$ ) (asterisks, lane 2), whereas Cm-activin is not $(51 \mathrm{kD})$ (asterisk, lane 3). Both XBMP-7 and XBMP-4 mRNA-injected oocytes produced cleaved amino-terminal peptides (34 and $35 \mathrm{kD}$, respectively) (asterisks, lanes 4,6). HA-Cm-XBMP-7 and Cm-XBMP-4 mRNAinjected oocytes failed to generate the cleaved polypeptides and produced only the uncleaved form (51 and $48 \mathrm{kD}$, respectively) (asterisks, lanes 5,7). Medium from HA-Cm-XBMP-7-injected oocytes was immunoprecipitated before SDS-PAGE (lane 5). Uninjected oocytes are shown in lane 1. HA-tagged Cm-XBMP-7 was found to have activity similar to Cm-XBMP-7. (C) Maturation of FlagXBMP-7 and Flag-XBMP-4 proteins is inhibited by expression of Cm-XBMP-7. (Lane 1) Uninjected oocytes; (lane 2) HA-Cm-XBMP-7 mRNA (50 ng)-injected oocytes. (Lanes 3 and 4, respectively) Injection of Flag-XBMP-7 or Flag-XBMP-4 mRNA (50 ng) results in the formation of cleaved precursor remainder peptides (asterisk at 34 and $35 \mathrm{kD}$, respectively) in addition to uncleaved monomers (arrowhead at 51 and $48 \mathrm{kD}$, respectively) and uncleaved dimers (arrow at 102 and $96 \mathrm{kD}$, respectively). (Lanes 5 and 6, respectively) Coinjection of Cm-XBMP-7 mRNA (200 ng) with Flag-XBMP-7 mRNA (50 ng) or Flag-XBMP-4 mRNA (50 ng) results in a decreased amount of precursor remainder peptide. This indicates that processing of Flag-XBMP-7 and Flag-XBMP-4 is inhibited in the presence of Cm-XBMP-7. (Lanes 7 and 8, respectively) Coinjection of Cm-activin mRNA (200 ng) with Flag-XBMP-7 mRNA (50 ng) or Flag-XBMP-4 mRNA $(50 \mathrm{ng}$ ) does not significantly reduce the formation of the precursor remainder peptide, indicating that the inhibition of processing is specific to the BMPs. Flag-tagged XBMP-7 and XBMP-4 were found to have similar, although slightly weaker, activity compared to native XBMP-7 and XBMP-4. All samples are run under nonreducing conditions. All lanes are immunoprecipitated with either the HA (lane 2 only) or Flag antibodies.

This may be attributable to the adhesive nature of the mature protein that could interact with the extracellular matrix and cell culture substrate, as has been shown for BMP-6 (vgr-1) (Lopez et al. 1992) and Drosophila dpp (Panganiban et al. 1990). Nevertheless, the presence of the precursor remainder peptides indicates that the wildtype molecules (uncleaved 51 and $48 \mathrm{kD}$, respectively) were cleaved. Consistent with this notion, expression of Cm-XBMP-7 and Cm-XBMP-4 mRNAs generated single species of 51 and $48 \mathrm{kD}$ polypeptides, respectively (Fig. $2 \mathrm{~B}$, lanes 5,7$)$. These results demonstrate that $\mathrm{Cm}-\mathrm{ac}$ tivin, Cm-XBMP-7 and Cm-XBMP-4 are not processed to yield mature ligands.

To determine whether $\mathrm{Cm}-\mathrm{XBMP}-7$ prevents the processing of XBMP-7 and XBMP-4, we coinjected Flagepitope tagged XBMP-7 and XBMP-4 with Cm-XBMP-7 mRNAs into oocytes. Injection of Flag-XBMP-7 and Flag-XBMP-4 mRNAs into oocytes, followed by immunoprecipitation with anti-Flag antibody results in the formation of precursor remainder peptides (Fig. 2C, lanes
3,4 , asterisks), as well as unprocessed monomers (Fig. $2 \mathrm{C}$, lanes 3,4, arrowhead) and unprocessed dimers (102 and $96 \mathrm{kD}$, respectively) (Fig. 2C, lanes 3,4, arrow). However, coinjection of Flag-XBMP-7 and Flag-XBMP-4 mRNA with Cm-XBMP-7 mRNA dramatically reduces the production of the precursor remainder peptide (Fig. $2 \mathrm{C}$, lanes 5,6 . These results indicate that the maturation of XBMP-7 and XBMP-4 protein is inhibited by the cleavage mutant, implying that Cm-XBMP-7 acts as a dominant negative. This inhibition of processing is specific to the BMPs, as coinjection of Flag-XBMP-7 and FlagXBMP-4 with $\mathrm{Cm}$-activin has little effect on the processing of the XBMP-7 and XBMP-4 polypeptides (Fig. $2 \mathrm{C}$, lanes 7,8 , respectively).

\section{Activities of the BMP cleavage mutants in Xenopus embryos}

To test the in vivo function of the cleavage mutants, synthetic mRNAs encoding the mutant proteins were 
microinjected into the ventral region of four-cell stage Xenopus embryos. It has been shown previously that interference with the BMP signaling pathway by injection of dominant-negative BMP receptors $(\triangle \mathrm{BR})$ dorsalizes ventral mesoderm (Graff et al. 1994; Suzuki et al. 1994). This dorsalization presumably occurs by inhibiting the normal suppression activity of the BMP signal already present in ventral marginal mesoderm, thereby inducing a secondary axis. If the $\mathrm{Cm}-\mathrm{XBMPs}$ are capable of blocking BMP signaling /perhaps by forming nonfunctional heterodimeric complexes with wild-type precursors), expression of the Cm-XBMPs could be expected to mimic the phenotypes of the dominant-negative BMP receptor in injection assays. Secondary axes were induced by the ventral expression of Cm-XBMP-7 $(85 \%, n=262)$ and Cm-XBMP-4 (92\%, $n=38$ ) (Fig. 3A and data not shown, respectively). Histological examination of the twinned embryos revealed that the induced secondary axes lacked the most extreme dorsal anterior tissues, such as head structures, but contained a secondary neural tube and notochord (Fig. 3B). This phenotype is indistinguishable from that of dominant-negative BMP receptor mRNAinjected embryos (Graff et al. 1994; Suzuki et al. 1994). Interestingly, ectopic expression of neither $\mathrm{Cm}$-activin $(n=41)$ nor wild-type $\mathrm{Vg}-1 \mid \mathrm{n}=37)$ (a nonprocessed TGF$\beta$-related molecule) induced secondary axes. These results suggest that $\mathrm{Cm}-\mathrm{XBMPs}$ can function as dominant-negative ligands in vivo and interfere with BMP signaling in the development of ventral mesoderm.

In situ hybridization analysis of XBMP-7 transcripts revealed that ectoderm is a major site of XBMP-7 expression (see Fig. 1). To investigate the function of XBMP-7 in the ectoderm, Cm-XBMP-7 mRNA was injected into all four animal blastomeres of eight-cell stage embryos, and the embryos were allowed to develop to later stages. The resulting embryos displayed enlarged anterior head

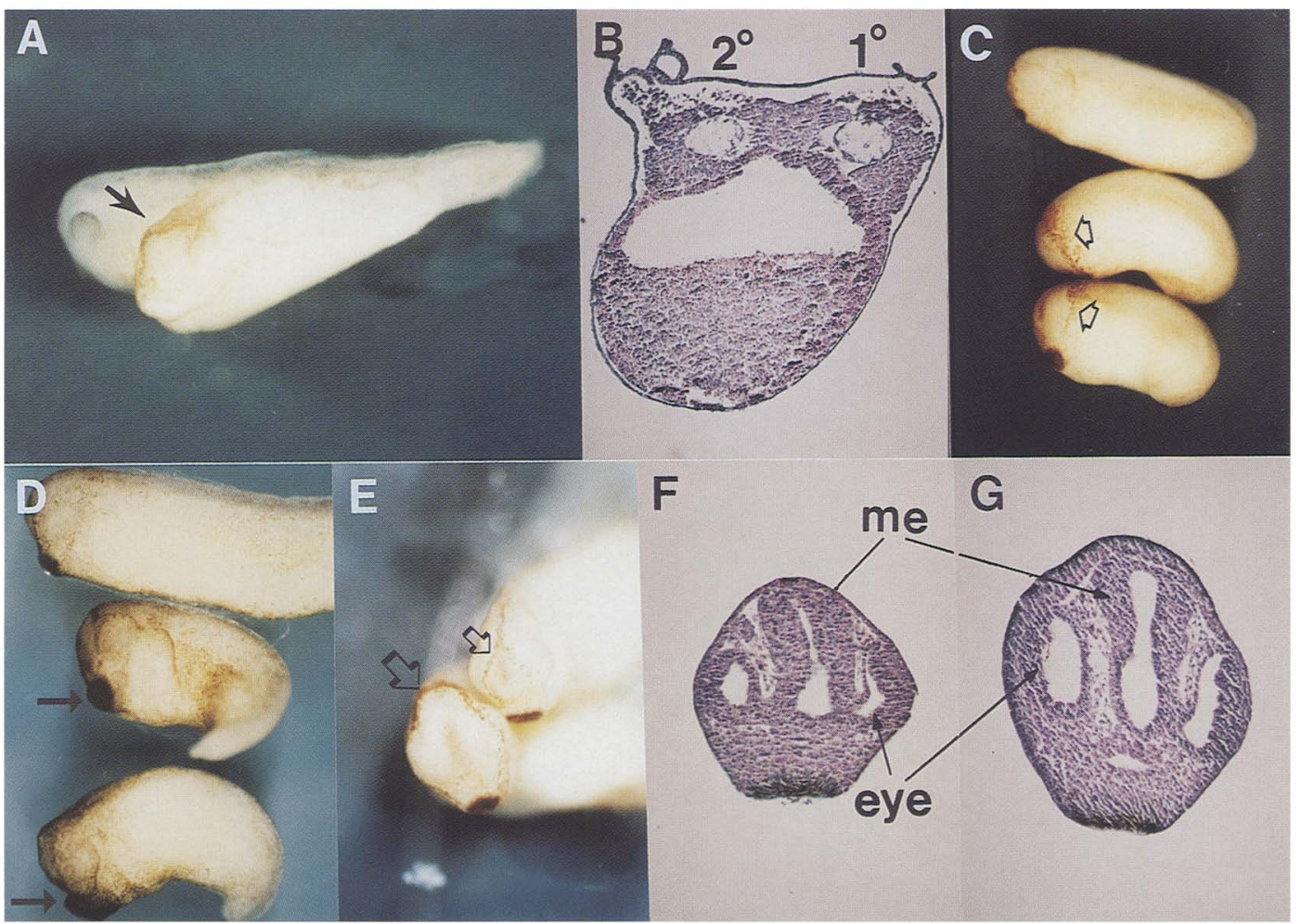

Figure 3. Ectopic expression of Cm-XBMP-7 induces secondary axes and large heads. $|A|$ Lateral view of a stage 35 embryo. Expression of Cm-XBMP-7 mRNA (4.0 ng) in the ventral marginal zone induces a secondary axis (arrow). (B) Transverse section of a stage $35 \mathrm{Cm}-\mathrm{XBMP}-7$ injected embryo. $\left(1^{\circ}\right)$ The primary axis $;\left(2^{\circ}\right)$ the secondary axis. Both the primary and secondary axes contain a neural tube and notochord. $(C)$ The large-head phenotype of stage 25 embryos. The bottom two embryos are Cm-XBMP-7 mRNA $(4.0$ ng)-injected embryos. At the top is a control embryo. The open arrows indicate the posteriorly expanded hatching glands. Note that the Cm-XBMP-7 mRNA-injected embryos are shorter relative to the control embryo. (D) The large-head phenotype of stage 30 embryos. The eyes are larger (as measured by diameter of the optic vesicle in transverse cross section shown in $F$ and $G$ ), and the embryos are twisted in Cm-XBMP-7 mRNA-injected embryos relative to the control embryo. The arrows indicate the extended cement glands, and the control embryo is at the top. $(E)$ Anterior view of large-head and control embryos. The large open arrow indicates the enlarged Cm-XBMP-7 hatching gland; the small open arrow indicates the normal size hatching gland of the control. $(F)$ Transverse sections of control and $(G)$ large-head phenotype embryos under identical magnification. Note that the eyes and head diameters are larger in Cm-XBMP-7 embryos than in the controls. (me) Mesencephalon. All embryos are oriented anterior to the left and dorsal to the top. 
structures that included expanded eyes, enlarged hatching glands, and protruding cement glands $(42 \%, n=38$; see Fig. 3C-E). Figure 3, F and G, represents a typical in scale comparison of transverse sections of the uniniected and Cm-XBMP-7 injected embryos. These results confirm that the anterior region is approximately twice the volume $(179 \%$ ) of a normal embryo (cf. the diameters of the mesencephalon and eye vesicles). Interestingly, the enlarged anterior structures are also accompanied by shortening of the embryos (Fig. $3 \mathrm{C}, \mathrm{D}$ ), suggesting that depletion of the XBMP-7 signal results in enlarged anterior structures, possibly at the expense of posterior structures. These results imply that XBMP-7 may be involved in anterior neuroectodermal determination. However, we are unable to conclude whether the ectopic expression of Cm-XBMP-7 influences the neuroectoderm patterning directly or indirectly through an influence on mesodermal patterning.

\section{Direct neural induction in embryonic ectoderm by $C m-X B M P S$}

Because the ectopic expression studies using whole embryos suggested that XBMP-7 might be involved in neuroectoderm determination, we tested the role of the XBMP-7 molecule in isolated animal cap ectoderm. After Cm-XBMP-7 mRNA was injected into all four blastomeres of four-cell stage embryos, animal caps were iso- lated at blastula stage (stage 8) and cultured in saline solution until sibling embryos reached tailbud stages (stage 25 or 35 equivalent). Although uninjected control animal caps differentiated into atypical epidermis (Fig. 4A), Cm-XBMP-7-injected animal caps formed ectopic cement glands (Fig. 4B), as confirmed by the presence of columnarized cells containing pigment granules (Fig. 4C) as well as the secretion of mucus (data not shown).

The cement gland is generally considered to be the most anterior structure patterned in response to neural induction (Sive et al. 1989; Drysdale and Elinson 1993). Because expression of Cm-XBMP-7 produced embryos with large anterior structures, as well as cement glands in isolated animal cap ectoderm, we tested the possibility that $\mathrm{Cm}-\mathrm{XBMP}-7$ might play a more general role in neural induction. RNA was isolated from the $\mathrm{Cm}-$ XBMP-7-injected animal caps at different stages of development and subjected to RT-PCR analysis for various markers (Fig. 5). Animal caps injected with $\mathrm{Cm}-\mathrm{XBMP}-7$ expressed the pan-neural marker $N$-CAM (Kintner and Melton 1987) (lanes 3,4), whereas control uninjected animal caps did not (lane 2). Induction of N-CAM was detected in animal caps injected with as little as $200 \mathrm{pg}$ of Cm-XBMP-7 mRNA (data not shown). To examine whether neural induction caused by ectopic expression of Cm-XBMP-7 occurs directly without the influence of mesoderm, expression of various mesodermal markers was examined. Neither muscle actin (a dorsal mesoder-
Figure 4. Cm-XBMP-7 induces cement glands in animal cap ectoderm. Animal cap explants from embryos injected with dominant-negative constructs. Uninjected control animal caps, at stage 35 equivalent, remain as atypical epidermis (A). Animal cap explants, at stage 35 equivalent, from $\mathrm{Cm}-$ XBMP-7 mRNA (0.8 ng)-injected embryos differentiate into cement glands $(B)$, as revealed by pigment aggregation. $(C)$ Histological sections of animal caps from $\mathrm{Cm}-$ XBMP-7 injected embryos at stage 40 equivalent. Open arrows indicate ectopic cement glands. $(D)$ Coinjection of wild-type XBMP-7 mRNA (0.8 ng) with Cm-XBMP-7 mRNA $(0.8 \mathrm{ng})$ blocks cement gland formation. $(E)$ Ectopic expression of wild-type activin mRNA $(0.5 \mathrm{ng})$ results in elongation of animal cap explants. $(F)$ Coinjection of wildtype activin mRNA (0.5 ng) with $\mathrm{Cm}$-activin mRNA (4.0 ng) rescues the epidermal phenotype.

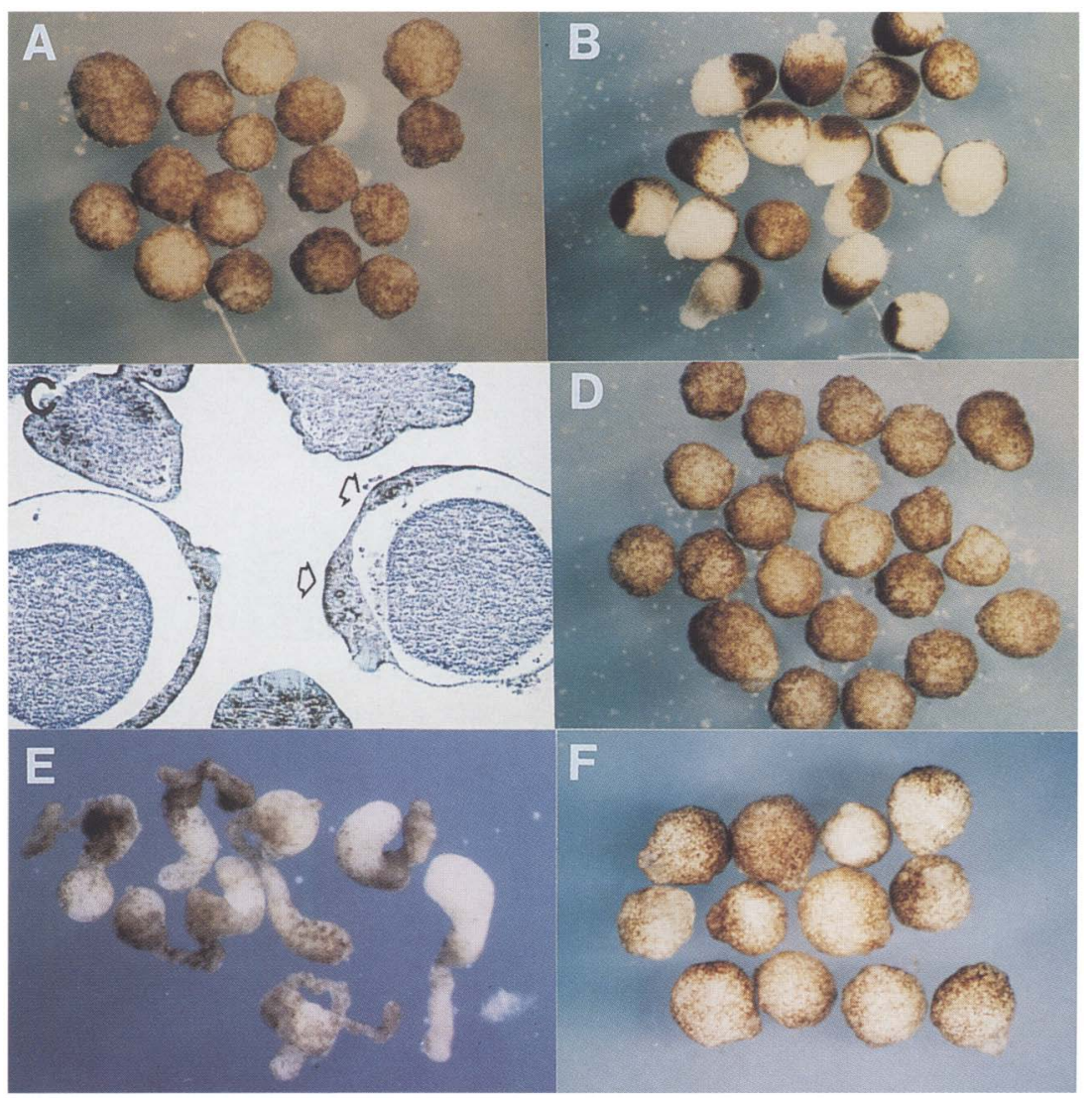




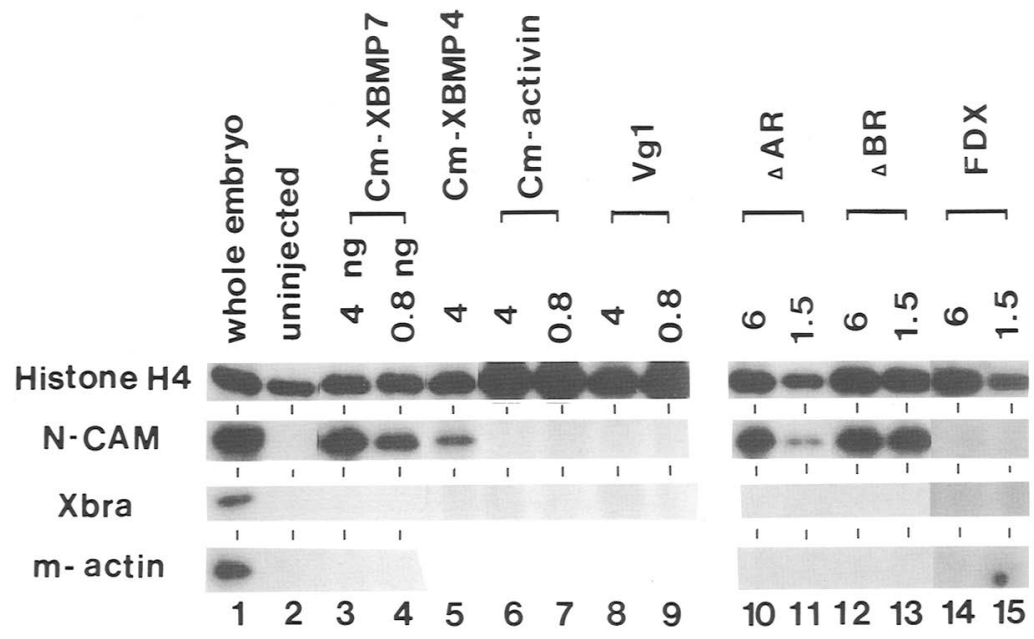

Figure 5. Specificity of neural induction by $\mathrm{Cm}-$ XBMPs. RT-PCR analysis of N-CAM, Xbra, and muscle actin marker expression. Whole embryo control (lane 1) and uninjected control animal caps (lane 2). Injection of Cm-XBMP-7 mRNA at 4.0 and $0.8 \mathrm{ng}$ (lanes 3,4) and Cm-XBMP-4 mRNA at $4.0 \mathrm{ng}$ (lane 5) induces N-CAM but not Xbra or muscle actin. Injection of $\mathrm{Cm}$-activin or Vg-1 mRNAs at 4.0 and $0.8 \mathrm{ng}$ (lanes 6-9) fails to induce $\mathrm{N}$-CAM. Injection of truncated activin $(\triangle \mathrm{AR})$ and BMP receptor $(\triangle \mathrm{BR})$ mRNAs $/ 6.0$ and $1.5 \mathrm{ng}$ ) induces N-CAM (lanes 10-13). Injection of truncated FGF receptor (FDX) mRNA at 6.0 and $1.5 \mathrm{ng}$ does not induce N-CAM expression (lanes 14,15). All samples are stage 30 equivalent. mal marker) nor brachyury (Xbra, a pan-mesodermal marker) were expressed in the Cm-XBMP-7-injected animal caps (Fig. 5, lanes 3,4, and Fig. 6). Interestingly, we also noted that injection of Cm-XBMP-7 mRNA did not induce noggin expression in animal cap ectoderm. Thus, neuralization after ablation of BMP signals appears to be independent of noggin (Fig. 6). From these experiments, we conclude that neuralization of prospective ectoderm by ectopic expression of Cm-XBMP-7 occurs directly, independent of both noggin signaling and mesoderm influence. We suggest that BMPs or BMP-related molecules are involved in the default mechanism of neuralization.

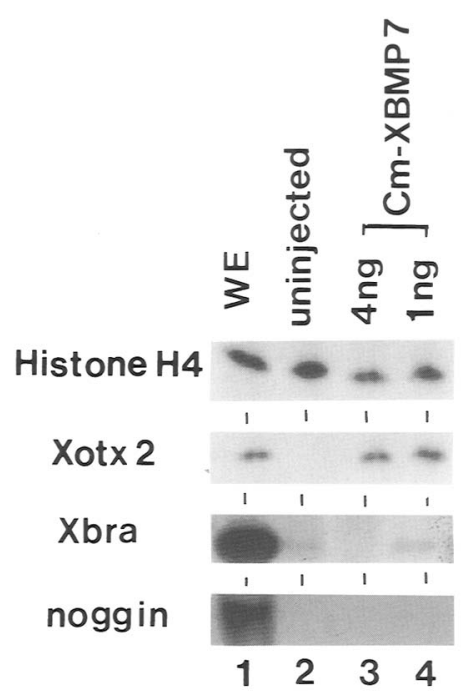

Figure 6. Neuralization by Cm-XBMP-7 occurs independently of noggin and mesoderm induction. RT-PCR analysis of histone $\mathrm{H} 4$, Xotx2, Xbra, and noggin markers. Whole embryos at gastrula stage (lane 1) and uninjected control animal caps (lane 2). Animal cap explants from embryos injected with Cm-XBMP-7 mRNA (4.0 and $1.0 \mathrm{ng}$ ) induce Xotx2 expression without the induction of Xbra or noggin (lanes 3,4). All samples are stage 11 equivalent.
Throughout these experiments truncated activin receptors $(\triangle \mathrm{AR})$ and truncated $B M P$ receptors $(\triangle B R)$ were also injected. As found previously (Hemmati-Brivanlou and Melton 19921, ectopic expression of truncated activin receptor mRNA in animal cap ectoderm induced $N$-CAM directly without the induction of detectable mesodermal marker expression (Fig. 5, lanes 10,11). We have found that ectopic expression of the truncated BMP receptor also induced N-CAM directly (Fig. 5, lanes 12,13 ), as has been reported recently by others (Sasai et al. 1995). Because ectopic expression of an equivalent amount of truncated basal fibroblast growth factor (bFGF) receptor (FDX) mRNA did not induce N-CAM (lanes 14,15), we conclude that neural induction mediated by the expression of truncated BMP or activin receptors is not attributable to non-specific injection artifacts. It is possible that ectopic expression of dominantnegative mutant activin receptors interacts with BMP receptors and interferes with BMP signaling, thus causing neural induction. This idea is consistent with the findings that activin type II-like receptors can interact with both type I activin and BMP receptors, and bind both activin and BMP(-like) ligands (Childs et al. 1993; Letsou et al. 1995; Ruberte et al. 1995; Yamashita et al. 1995). Perhaps, depending on the context, the binding of different type II class receptors with various type I class receptors may mediate either BMP or activin signaling.

Neuralization by $C m-X B M P s$ is attributable to specific inhibition of BMP signaling pathways

To gauge the specificity of Cm-XBMP-7 on neural induction, we compared the effects of two additional cleavage mutants, Cm-XBMP-4 and Cm-activin, and Vg-1. Neural induction in animal caps injected with $\mathrm{Cm}-$ XBMP-4 mRNA was indistinguishable from that of CmXBMP-7 both by external morphological criteria /data not shown) and by induction of neural markers (Fig. 5, lane 5). Next, we examined whether another TGF- $\beta$-related cleavage mutant could mimic the neuralizing phe- 
notype of $\mathrm{Cm}-\mathrm{XBMP}-7$ using $\mathrm{Cm}$-activin. Functionality of $\mathrm{Cm}$-activin was tested using an animal cap elongation assay. Although animal caps injected with activin mRNA elongated (Fig. 4E), animal caps coinjected with activin and $\mathrm{Cm}$-activin mRNAs did not (Fig. 4F). This blockage of elongation was specific as coinjection of Cm-XBMP-7 with activin mRNAs did not block elongation (data not shown). The results suggest that $\mathrm{Cm}-$ activin, but not $\mathrm{Cm}-\mathrm{XBMP}-7$, can block specifically activin function. Conversely, animal caps injected with Cm-XBMP-7 and Cm-XBMP-4 mRNAs were still capable of responding to activin, as judged by an animal cap elongation assay (data not shown). Thus, blocking of BMP signaling by Cm-XBMP-7 and Cm-XBMP-4 is specific for BMPs. We then examined the role of $\mathrm{Cm}$-activin and $\mathrm{Vg}-\mathrm{l}$ in neural induction by ectopic expression in animal cap ectoderm. Neither $\mathrm{Cm}$-activin nor $\mathrm{Vg}-1$ were able to induce neural tissues (Fig. 5, lanes 6-9). These data suggest that neural induction occurs by specific inhibition of BMP signaling and that instead of activin, BMPs may be involved in the repression of neural induction.

To further examine the specificities of the Cm-XBMPs, rescue experiments were conducted. We found that coinjection of Cm-XBMP-7 with either wild-type XBMP-7 or XBMP-4 prevented animal cap ectoderm from differentiating into neuroectoderm, as revealed by the disappearance of cement gland tissue (Fig. 4D; data not shown) as well as the extinction of expression of the neural marker N-CAM (Fig. 7, cf. lane 3 with lanes 4 and 5). Similarly, neural induction by Cm-XBMP-4 was rescued by coinjection of either wild-type XBMP-4 or XBMP-7 mRNAs (Fig. 7, cf. lane 6 with lanes 7 and 8) back to an epidermal fate. From these experiments we conclude that neuralization by Cm-XBMPs can be rescued by coinjection of either wild-type XBMP-4 or wildtype XBMP-7.

\section{Ablation of BMP signaling induces anterior neuroectoderm}

It has been proposed that at least two signals are required for the anterior-posterior patterning of the neuroectoderm; one signal instructs the development of anterior neuroectoderm and another instructs posterior structures (Nieuwkoop 1952). Thus, we wished to examine the extent of the neural patterning capability of ectoderm after ablation of BMP signals. Figure 8 shows the results of RT-PCR analysis of the expression of various neural marker genes in Cm-XBMP-7 mRNA-injected animal cap explants at stage 25 equivalent. XAG1 is a marker for cement gland, the most anterior ectodermal structure (Sive et al. 1989). Xotx2 is a marker for both the forebrain and mid-brain regions (Blitz and Cho 1995; Pannese et al. 1995); Krox 20 is expressed in rhombomeres 3 and 5 of the hindbrain (Bradley et al. 1993), whereas XlHbox6 (HoxB.9) is expressed in the spinal cord (Wright et al. 1990). Injection of Cm-XBMP-7 or $\mathrm{Cm}$-XBMP-4 results in induction of anterior marker genes such as XAG1 and Xotx2 in isolated animal caps,
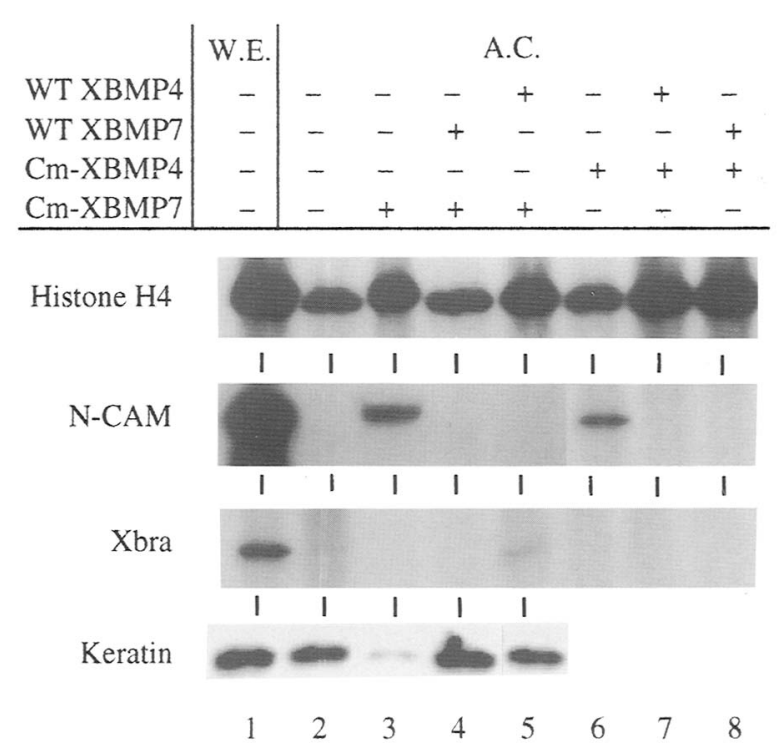

Figure 7. Neuralization by $\mathrm{Cm}-\mathrm{XBMPs}$ is rescued by either wild-type XBMP-7 or XBMP-4. RT-PCR analysis of N-CAM, $\mathrm{Xbra}$, and keratin markers using RNA samples isolated at stage 30 equivalent. Whole control embryos (lane 1) and uninjected control animal caps (lane 2). Although ectopic expression of Cm-XBMP-7 mRNA $(0.8 \mathrm{ng})$ induces N-CAM and inhibits keratin expression (lane 3), coinjection with wild-type XBMP-7 (lane 4) or XBMP-4 (lane 5) mRNA (0.8 ng) blocks neural induction and rescues keratin expression. Ectopic expression of $\mathrm{Cm}-$ XBMP-4 mRNA also induces N-CAM (lane 6), and coinjection with wild-type XBMP-4 (lane 7) or XBMP-7 (lane 8) mRNA $\{0.8$ $n g)$ again represses neural induction.

whereas a posterior marker, $X 1 H b o x 6$, is uninduced (Fig. 8 , lanes 3,4 ; data not shown). This is similar to the induction of anterior marker genes by dominant-negative activin $(\triangle \mathrm{AR})$ and $\mathrm{BMP}(\triangle \mathrm{BR})$ receptors (lanes 5-8). The hindbrain marker Krox 20 is weakly induced (lanes $4,5,8)$, but the significance of this weak expression is not clear. It is also noteworthy to mention that the posterior spinal cord marker XIHBOX6 could not be induced by microinjection of Cm-XBMPs, suggesting that the establishment of posterior neural fate may require as yet unidentified factors.

\section{Discussion}

\section{Disruption of BMP signals promotes neuralization}

In this study, we demonstrate that blocking BMP signaling using cleavage mutants leads to direct neuralization of embryonic ectoderm without the prior induction of mesoderm. We propose that BMP ligands may be involved in the maintenance of ectodermal cell differentiation during early Xenopus embryogenesis and that neuralization occurs by inhibition of BMP signals in the ectoderm. The notion that neuralization represents a default state of the ectoderm has been proposed previously (Godsave and Slack 1989; Grunz and Tacke 1989; Hemmati-Brivanlou and Melton 1994) and activin has been suggested to be involved in this process. In this 

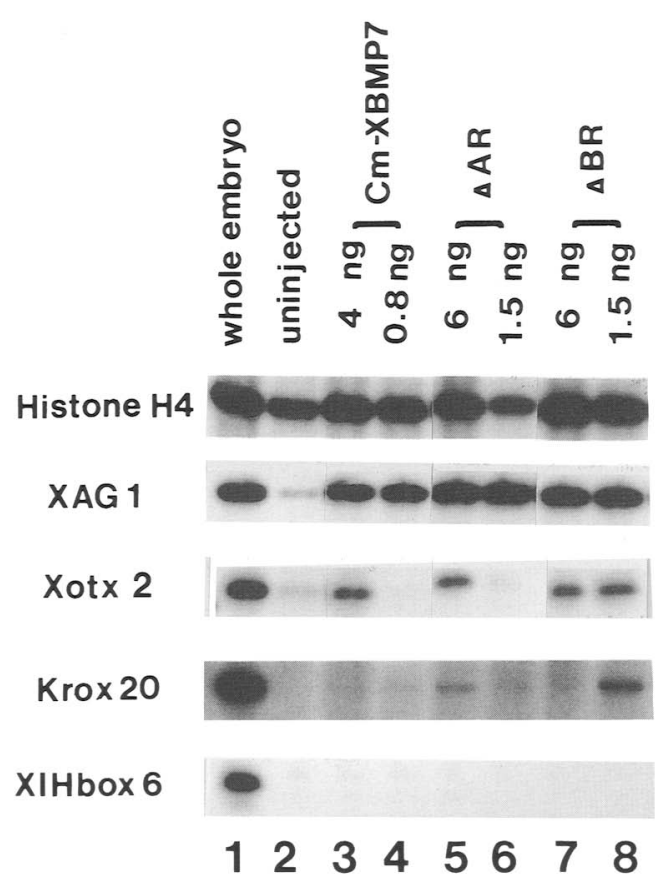

Figure 8. $\mathrm{Cm}-\mathrm{XBMP}-7$ induces anterior neuroectoderm markers but not posterior ones. RT-PCR analysis of XAG1, Xotx2, Krox20, and XlHbox 6 markers. Whole control embryos (lane 1) and uninjected control animal caps (lane 2). Injection of $\mathrm{Cm}$ XBMP-7 mRNA at 4.0 and $0.8 \mathrm{ng}$ induces $X A G 1$, but Xotx 2 is induced only at $4.0 \mathrm{ng}$ (lanes 3,4). Injection of 6.0 and $1.5 \mathrm{ng}$ truncated activin $(\triangle \mathrm{AR})$ and $\mathrm{BMP}(\triangle \mathrm{BR})$ receptor mRNAs induce anterior (XAG1, Xotx2) but not posterior markers (Krox 20, $\mathrm{XlHbox} 6$ ) (lanes 5-8). All samples are stage 25 equivalent.

paper, we propose that, instead of activin, BMPs are the major extracellular components of this default pathway of neural induction.

Several observations support our hypothesis. First, BMPs have the correct spatiotemporal profile to be involved in the process of neuralization. We suggest that the ordinary BMP signals in animal cap cells direct the cells toward an epidermal fate and inhibit the production of neural tissue. Thus, autonomous neural induction observed in dissociated embryonic ectodermal cells (Godsave and Slack 1989; Grunz and Tacke 1989) is a result of a dilution of the BMP signals already present in the ectoderm. Consistent with this idea, transcripts for both BMP ligands and receptors are present in blastula animal caps (Nishimatsu et al. 1992a; Graff et al. 1994), and BMP-4 has been shown to be involved in the specification of ectodermal tissue in Xenopus (Wilson and Hemmati-Brivanlou 1995). Second, this model would explain the conflicting results between mouse and Xenopus regarding the role of activin in neural induction. Although expression of a truncated activin receptor in Xenopus suggests a role for activin in neural induction, mice deficient in either activins $\beta_{A}$ and $\beta_{B}$, or activin receptor type II displayed no significant defects in neural tissue formation (Matzuk et al. 1995a,b). It may be that in Xenopus, ectopic expression of a dominant-negative ac- tivin type II receptor results in interference of BMP signaling. Consistent with this idea, truncated activin receptor has been shown to block the function of other members of the TGF- $\beta$ superfamily including BVg-1 (Schulte-Merker et al. 1994), and BMPs (this study; Wilson and Hemmati-Brivanlou 1995; N. Ueno, pers. comm.). In addition, native activin type II receptor has been shown to interact with type I BMP receptor (Yamashita et al. 1995).

Although activin has been implicated in mesodermal and neural tissue induction, no maternal activin transcripts have been detected (Thomsen et al. 1990). Thus, it has been suggested that in Xenopus, maternally deposited activin protein may be responsible for mesoderm induction and the repression of neural induction (Asashima et al. 1991). Our experiments using the activin cleavage mutant $(\mathrm{Cm}$-activin $)$ disfavor a role for activin in neural induction. However, we cannot exclude the possibility of the involvement of maternal activin protein in neural induction. As maternal activin protein is expected to be already dimerized and processed before the expression of the $\mathrm{Cm}$-activin protein, it is unlikely that $\mathrm{Cm}$-activin is effective in neutralizing the activity of activin protein of maternal origin.

Our approach of using cleavage mutants to inhibit BMP signaling appears to be specific for the BMPs. First, expression of the cleavage mutants of both XBMP-7 and XBMP-4 neuralize the ectoderm, but similar injection of $\mathrm{Cm}$-activin or wild-type Vg-1 mRNAs fail to do so. Second, dominant-negative TGF- $\beta 1$ fails to inactivate BMP-6 in cotransfection assays (Lopez et al. 1992). Third, the cleavage mutant of activin influenced only the activity of activin, but not that of BMP-4 (Wittbrodt and Rosa 1994). From this evidence, we conclude that BMP cleavage mutants act only on the BMP subset of the TGF- $\beta$ superfamily.

\section{Speculation on the mechanisms of neural induction in Xenopus}

Both XBMP-7 and XBMP-4 are expressed uniformly in ectoderm during early gastrula stages, and ablation of the BMP signal leads to the induction of anterior neural markers. These findings are consistent with the traditional view of anterior-posterior neuroectoderm patterning. Because inhibition of BMP signals can induce anterior neuroectoderm, it may be that the long sought after neural inducers are molecules that can antagonize BMP signaling. In this regard it should be noted that Xenopus chordin (a gene specifically expressed in the organizer) is antagonized by BMP-4 and induces neural tissues (Sasai et al. 1995). Perhaps during gastrulation when the invaginating mesoderm contacts the overlying neuroectoderm, chordin may be secreted from the organizer and act as an endogenous neural inducer by inhibiting BMP activities in the ectoderm. As mentioned earlier, chordin is related to Drosophila sog. sog behaves genetically as an antagonist of $d p p$ (Ferguson and Anderson 1992), and has been suggested to be involved in neural specification in Drosophila (Francois et al. 1994). 
Noggin has been proposed to be a neural-inducing factor in Xenopus. The noggin gene is expressed in the organizer and at high concentration, noggin protein can directly induce anterior neural markers in isolated animal cap ectoderm (Lamb et al. 1993). The fact that CmXBMP-7 does not induce noggin gene expression implies that the pathway of neuralization by ablation of BMP signals is distinct from the noggin pathway. It may be that neural induction in amphibians is attained by two independent signaling pathways, noggin dependent and BMP dependent. Alternatively, noggin may attenuate BMP activity.

\section{Conservation of BMP signaling components during evolution}

Components of TGF- $\beta$ signaling pathways have been highly conserved during evolution. In Drosophila, ectodermal differentiation is regulated by both $d p p$ and screw (scw) (Ferguson and Anderson 1992; Arora et al. 1994), members of the TGF- $\beta$ superfamily of secreted molecules. $d p p$ is related most closely to vertebrate BMP-2 and BMP-4, whereas $s c w$ is closest to BMP-7 and BMP-6 (Arora et al. 1994). Functional conservation between BMP-4 and $d p p$ has been demonstrated by rescue of $d p p$ mutants by BMP-4 expression in early Drosophila development (Padgett et al. 1993). Genetic studies in Drosophila suggest that $d p p$ interacts with $s c w$, possibly by forming a heterodimer to specify a dorsal fate (Arora et al. 1994). Similarly, Xenopus BMP-7 and BMP-4 have been shown to form heterodimeric proteins in vivo (Hazama et al. 1995), and could suggest a common mechanism whereby XBMP-7 attenuates the activity of XBMP-4. Formation of heterodimeric complexes between BMP-7 and BMP-4 is attractive as this model explains why ectopic expression of both Cm-XBMP-7 and Cm-XBMP-4 have identical neural-inducing phenotypes.

The Drosophila tolloid (tld) gene, which functions in concert with $d p p$ and $s c w$ to pattern the dorsal region of the embryo, encodes a metalloprotease that shares extensive sequence similarity with mammalian BMP-1 (Shimell et al. 1991). BMP-1 was originally purified from demineralized bone extracts as a member of a group of $30-\mathrm{kD}$ proteins that included BMP-2 and BMP-4 (Wozney et al. 1988), and vertebrate homologs of tld have been cloned in human, mouse, and Xenopus (Maeno et al. 1993; Fukagawa et al. 1994). Furthermore, as mentioned above, Drosophila sog is related to Xenopus chordin and they have been shown to be functionally interchangeable (Holley et al. 1995). In consideration of the functional conservation of these components of the BMP signaling processes between Drosophila and vertebrates, we suggest that the molecular mechanisms underlying ectodermal differentiation and neural induction are likely to have been preserved throughout animal evolution.

\section{Materials and methods}

\section{Molecular cloning}

A mixed gastrulae cDNA library was screened with 512-fold degenerate oligonucleotides. Hybridization and subsequent washing were performed as described previously (Blumberg et al. 1991) and exposed to X-ray film. The cDNA inserts from candidate clones were subjected to in vivo excision according to the manufacturer's instructions (Stratagene) and the XBMP-7 and XBMP-4 cDNAs were sequenced using the Sanger dideoxy method. A 1622-bp EcoRI-XhoI fragment was subcloned into pBluescript (SK -).

\section{Generation of constructs}

Overlapping PCR was used to generate dominant-negative constructs of XBMP-7, XBMP-4, and activin that encode the conserved peptide cleavage sequences RSVR (CGCAGTGTTCGA), RSKR (AGGTCAAAAAGA), and RKKR (AGAAAAAAACGT), respectively. The cleavage sites were altered to GVDG (GGCGTCGACGGA or GGCGTCGACGGT), containing a Sall restriction site. For the generation of $\mathrm{Cm}-\mathrm{XBMP}-7$ the first round of PCR consisted of two primer pairs for the generation of the upstream and downstream portions of the molecule. The generation of the amino portion of Cm-XBMP-7 was conducted with upstream T3 primer and downstream primer (5'GACGGGTCGACGCCGAGATGGATATCTGAGGT-3'). The generation of the carboxyl portion was conducted with upstream primer $\left(5^{\prime}\right.$-GACGGGTCGACGGATCTACTAGCAACAAGCAC- $3^{\prime}$ ) and downstream $\mathrm{T} 7$ primer. The conditions of the PCR reactions were 30 cycles of $92^{\circ} \mathrm{C}$ for $1 \mathrm{~min}, 55^{\circ} \mathrm{C}$ for 2.5 $\mathrm{min}, 72^{\circ} \mathrm{C}$ for $2.5 \mathrm{~min}$, followed by a final step of $10 \mathrm{~min}$ at $72^{\circ} \mathrm{C}$. PCR products were purified on agarose gels and then digested with Sall. Fragments were ligated together using T4 DNA ligase, and then amplified through a second round of PCR using the T3 and T7 primers. The final PCR product was purified on an agarose gel and then digested with HindIII. The HindIII 645-bp digestion product was purified on an agarose gel. pBluescript (SK -) XBMP-7 was also digested with HindIII to remove the 645-bp internal fragment. The mutated HindIII PCR product was then ligated into the pBluescript (SK -) XBMP-7 vector, resulting in pBluescript $(\mathrm{SK}-) \mathrm{Cm}-\mathrm{XBMP}-7$. Proper orientation was confirmed by restriction mapping. Cm-XBMP-4 and $\mathrm{Cm}$-activin were generated by the same methodology as Cm-XBMP-7 with the exception of the upstream and downstream primers used in the first round of amplification: Cm-XBMP-4 upstream 15'-GGGGTCGACGCCCCTAGTCAGTGCATGCCC-3') and downstream (5'-GGGGTCGACGGAAGTCCAAAACAGCAGAGA-3' ${ }^{\prime}$; and Cm-activin upstream (5'-TAAGCCACCGTCGACGCCTCTATGGGGGTGCTCATC-3'), and downstream (5'-CATAGAGGCGTCGACGGTGGCTTAGAGTGTGATGG-3').

pSP64-Xßm (Krieg and Melton 1984; Melton et al. 1984) contains a $\beta$-globin $5^{\prime}$ leader sequence immediately upstream of the initiator methionine. For the creation of $\mathrm{pSP} 64-\mathrm{X} \beta \mathrm{m}$ versions of XBMP-7 and Cm-XBMP-7, the two pBluescript (SK - ) constructs [pBluescript (SK - X XBMP-7 and pBluescript (SK - ) CmXBMP-7] were PCR amplified with the $\mathrm{N}$ (5'-GGGGGTTAACATGAATGCTTTGACAGTAAAG-3') and T7 primers. These fragments were digested with $\mathrm{HpaI}, B g I \mathrm{II}$, and ApaI. The HpaI$B g$ III 160-bp fragment and the BgIII-ApaI 1133-bp fragment were isolated and subjected to ligation with $M s c I-A p a I$-digested pSP64-X $\beta \mathrm{m}$.

Cm-XBMP-7 was tagged with a hemagglutinin (HA) epitope using overlapping PCR. The PCR conditions were 1 cycle of $94^{\circ} \mathrm{C}$ for $1 \mathrm{~min}, 50^{\circ} \mathrm{C}$ for $1 \mathrm{~min}, 72^{\circ} \mathrm{C}$ for $1 \mathrm{~min}$; then 29 cycles of $94^{\circ} \mathrm{C}$ for $1 \mathrm{~min}, 55^{\circ} \mathrm{C}$ for $1 \mathrm{~min}$, and $72^{\circ} \mathrm{C}$ for $1 \mathrm{~min}$. The amino portion was generated with the primer pair SP6 and 5'-CCCGGATCCGACAAAACTAGAGTGGAAATC-3'. The carboxyl portion was generated with the primer pair $5^{\prime}-\mathrm{GG}^{-}$ 
CGGATCCTATCCATATGATGTGCCAGATTATGCTCAG-3' and T7. PCR products were purified on agarose gels, digested with BamHI and HindIII, and then ligated into the HindIII digested $\mathrm{pSP} 64-\mathrm{X} \beta \mathrm{m}-\mathrm{XBMP}-7$ vector.

XBMP-7 and XBMP-4 were tagged with a Flag epitope using synthesized oligonucleotides coding for the Flag amino acid sequence (DYKDDDDK). The oligonucleotides used were 7-top, 5'-GATCGATTATAAGGATGATGATGATAAGGATCC-3'; 7-bottom, 5'-GATCGGATCCTTATCATCATCATCCTTATAATC-3'; 4-top, 5'-AGATTATAAGGATGATGATGATAAGGATCCAATGCA-3'; and 4-bottom, 5'-TTGGATCCTTATCATCATCATCCTTATAATCTTGCA-3'. The top and bottom oligonucleotides were mixed and then ligated into linearized (digested with BglII and PstI, respectively| XBMP-7 and XBMP-4 constructs.

\section{Fertilization and manipulation of embryos}

Xenopus laevis eggs were collected in high salt modified Barth's solution (H-MBS) and fertilized in vitro (Cho et al. 1991). Embryos were dejellied using $2 \%$ cysteine, washed with $0.1 \times$ MBS, transferred into petri dishes containing $0.1 \times$ MBS over a $1 \%$ agarose bottom, and staged according to Nieuwkoop and Faber (1967). Animal cap ectoderm was dissected at late blastula stage in $1 \times$ MBS. The animal caps were allowed to remain in $1 \times$ MBS for $15 \mathrm{~min}$ postexplantation, then transferred to $0.3 \times \mathrm{MBS}$ and allowed to develop to later stages.

\section{Whole-mount in situ hybridization}

In situ hybridization was performed essentially as described previously (Harland 1991). A 645-bp HindIII fragment of the XBMP-7 cDNA was subcloned into pBluescript (SK - | resulting in pXBMP-7 (H645). Antisense probe was generated by digesting pXBMP-7 (H645) with EcoRI and transcribing with T3 RNA polymerase. Sense pXBMP-7 (H645) control probes were generated by digesting with $X$ hoI and transcribing with $T 7$ RNA polymerase.

Preparation of synthetic $m R N A$, microiniection, and in vivo translation

Plasmids X $\beta \mathrm{m}-\mathrm{XBMP}-7$ and X $\beta \mathrm{m}-\mathrm{XBMP}-4$ were digested with $X h o I$, and $X \beta \mathrm{m}$-activin was digested with $E$ coRI to linearize the plasmids. The linear plasmids were transcribed using the SP6 MEGAscript kit (Ambion). All mRNAs used for microinjection were capped with $\mathrm{m} 7 \mathrm{G}\left(5^{\prime}\right) \mathrm{ppp}\left(5^{\prime}\right) \mathrm{G}$. mRNAs were injected into the desired blastomeres of four- to eight-cell stage embryos after sorting according to their pigmentation patterns as described previously (Cho et al. 1991). The injection volume was $4 \mathrm{nl}$ into each blastomere at the concentrations indicated. All injections were performed in $1 \times \mathrm{MBS}$, and $50 \mathrm{~min}$ after injection, all injected embryos were transferred back into $0.1 \times \mathrm{MBS}$ and kept at room temperature for further development.

Oocytes were removed from mature females, manually defolliculated, injected with 50-250 ng of in vitro-transcribed mRNA, and pulse-labeled with $\left.{ }^{35} S\right]$ methionine as described previously (Wittbrodt and Rosa 1994). In coinjection experiments, 50 ng of Flag-XBMP-7 or Flag-XBMP-4 mRNA and 200 $\mathrm{ng}$ of $\mathrm{Cm}-\mathrm{XBMP}-7$ or $\mathrm{Cm}$-activin mRNA was coinjected. Aliquots of the incubation media from 20 injected oocytes were analyzed on $14 \%$ SDS-PAGE and autoradiographed. Immunoprecipitations of epitope-tagged proteins were carried out from oocyte lysates (from 20 oocytes) and incubation media, using protein-A-Sepharose beads (Sigma), as described previously (Harlow and Lane 1988), and then analyzed on 12\% SDS-PAGE and autoradiographed. Anti-HA antibody 12CA5 was purchased from Berkeley Antibody Company, Richmond, CA. Polyclonal anti-Flag antibody was purchased from Santa Cruz Biotech, Santa Cruz, CA.

\section{$R T-P C R$}

Total RNA was extracted from embryos and animal cap explants at the stages indicated using RNAzol (Cinna/Biotecx) according to manufacturer's instructions. RT-PCR was performed as described previously (Blitz and Cho 1995). The oligonucleotide primers used were specific for histone $H 4$ (F: 5'-CGGGATAACATTCAGGGTATCACT-3'; R: 5'-ATCCATGGCGGTAACTGTCTTCCT- $3^{\prime}$ ), N-CAM (F: 5'-AGATGCAGTCATTATTTGTGATGTC-3'; R: 5'-CTGGATGTCCTTATAGTTGATCTC-3') (Collett and Steele 1993); keratin (F: 5'-CACCAGAACACAGAGTAC-3'; R: 5'-CAACCTTCCCATCAACCA-3') (Wilson and Melton 1994); and Xotx2 (F: 5'-GGAGGCCAAAACAAAGTG-3'; R: 5'-TCATGGGGTAGGTCCTCT-3') (Blitz and Cho 1995); Muscle actin (F: 5'-GCTGACAGAATGCAGAAG-3'; R: 5'-TTGCTTGGAGGAGTGTGT-3'); Xbra (F: 5'-GGATCGTTATCACCTCTG-3'; R: 5'-GTGTAGTCTGTAGCAGCA-3'); Krox 20 (F: 5'-AACCGCCCCAGTAAGACC-3'; R: 5'-GTGTCAGCCTGTCCTGTTAG-3'); and XlHbox6 (F: 5'-TACTTACGGGCTTGGCTGGA-3'; R: 5'-AGCGTGTAACCAGTTGGCTG-3') (Hemmati-Brivanlou et al. 1994; Hemmati-Brivanlou and Melton 1994).

\section{Histology}

Embryos and animal caps were fixed in Bouin's solution for 60 min, then cleared with repeated $70 \%$ ethanol washes. Cleared embryos were embedded in Paraplast (Oxford Labware) embedding medium and sectioned as described previously /Cho et al. 1991). Sections were stained with Gill's hematoxylin stain formulation \#3 (Fischer) and counterstained with Light Green (Cho et al. 1991).

\section{Acknowledgments}

We thank Drs. N. Ueno and G. Thomsen for the activin cDNAs, and Drs. G. Thomsen and D. Melton for the Vg-1 cDNA. Dominant-negative BMP, activin, and FGF receptors were gifts from Drs. N. Ueno, A. Hemmati-Brivanlou, and E. Amaya, respectively. We also wish to acknowledge Dr. N. Ueno for communicating his results before publication. We thank M. Artinger, Drs. I. Blitz and A. Candia for critical reading of the manuscript. Initial isolation of XBMP-7 cDNA was carried out in the laboratory of Dr. E. DeRobertis. This work was supported by National Institutes of Health grant HD29507, the Pew Scholars Program, and a grant from the March of Dimes. C. Hashimoto was supported by Japan Society for the Promotion of Science.

The publication costs of this article were defrayed in part by payment of page charges. This article must therefore be hereby marked "advertisement" in accordance with 18 USC section 1734 solely to indicate this fact.

\section{References}

Arora, K., M.S. Levine, and M.B. O'Connor. 1994. The screw gene encodes a ubiquitously expressed member of the TGF- $\beta$ family required for specification of dorsal cell fates in the Drosophila embryo. Genes \& Dev. 8: 2588-2601.

Asashima, M., H. Nakano, K. Shimada, K. Kinoshita, K. Ishii, H. 
Shibai, and N. Ueno. 1990. Mesoderm induction in early amphibian embryos by activin A /erythroid differentiation factor). Wilhelm Roux's Arch. Dev. Biol. 198: 330-335.

Asashima, M., H. Nakano, H. Uchiyama, H. Sugino, T. Nakamura, Y. Eto, D. Ejima, S. Nishimatsu, N. Ueno, and K. Kinoshita. 1991. Presence of activin /erythroid differentiation factor) in unfertilized eggs and blastulae of Xenopus laevis. Proc. Nat1. Acad. Sci. 88: 6511-6514.

Blitz, I.L. and K.W.Y. Cho. 1995. Anterior neuroectoderm is progressively induced during gastrulation: The role of the Xenopus homeobox gene orthodenticle. Development 121: 993-1004.

Blumberg, B.W., C.V.E. Wright, E.M. DeRobertis, and K.W.Y. Cho. 1991. Organizer-specific homeobox genes in Xenopus laevis embryos. Science 253: 194-196.

Bradley, L.C., A. Snape, S. Bhatt, and D.G. Wilkinson. 1993. The structure and expression of the Xenopus Krox-20 gene: Conserved and divergent patterns of expression in rhombomeres and neural crest. Mech. Dev. 40: 73-84.

Childs, S.R., J.L. Wrana, K. Arora, L. Attisano, M.B. O'Connor, and J. Massague. 1993. Identification of a Drosophila activin receptor. Proc. Natl. Acad. Sci. 90: 9475-9479.

Cho, K.W.Y., B. Blumberg, H. Steinbeisser, and E. M. DeRobertis. 1991. Molecular nature of Spemann's organizer: The role of the Xenopus homeobox gene goosecoid. Cell 67: 11111120 .

Collett, J.W. and R.E. Steele. 1993. Alternative splicing of neural-specific Src mRNA ( $\mathrm{Src}+$ ) is a rapid and protein synthesis-independent response to neural induction in Xenopus laevis. Dev. Biol. 158: 487-495.

Dale, L., G. Howes, B.M.J. Price, and J.C. Smith. 1992. Bone Morphogenetic Protein 4: A ventralizing factor in early $\mathrm{Xe}$ nopus development. Development 115: 573-585.

Drysdale, T.A. and R.P. Elinson. 1993. Inductive events in the patterning of the Xenopus laevis hatching and cement glands, two cell types which delimit head boundaries. Dev. Biol. 158: 245-253.

Fainsod, A., H. Steinbeisser, and E.M. DeRobertis. 1994. On the function of $B M P-4$ in patterning the marginal zone of the Xenopus embryo. EMBO I. 13: 5015-5025.

Ferguson, E.L. and K.V. Anderson. 1992. Localized enhancement and repression of the activity of the TGF- $\beta$ family member, decapentaplegic, is necessary for dorsal-ventral pattern formation in the Drosophila embryo. Development 114: 583-597.

Francois, V., M. Solloway, J.W. O'Neill, J. Emery, and E. Bier. 1994. Dorsal-ventral patterning of the Drosophila embryo depends on a putative negative growth factor encoded by the short gastrulation gene. Genes \& Dev. 8: 2602-2616.

Fukagawa, M., N. Suzuki, B.L. Hogan, and C.M. Jones. 1994. Embryonic expression of mouse bone morphogenetic protein-1 (BMP-1), which is related to the Drosophila dorsoventral gene tolloid and encodes a putative astacin metalloendopeptidase. Dev. Biol. 163: 175-183.

Godsave, S.F. and J.M. Slack. 1989. Clonal analysis of mesoderm induction in Xenopus laevis. Dev. Biol. 134: 486-490.

Graff, J.M., R.S. Thies, J.J. Song, A.J. Celeste, and D.A. Melton. 1994. Studies with a Xenopus BMP receptor suggest that ventral mesoderm-inducing signals override dorsal signals in vivo. Cell 79: 169-179.

Grunz, H. and L. Tacke. 1989. Neural differentiation of Xenopus laevis ectoderm takes place after disaggregation and delayed reaggregation without inducer. Cell Differ. Dev. 28: 211217.

Harland, R.M. 1991. In situ hybridization: An improved wholemount method for Xenopus embryos. Methods Cell. Biol.
36: 685-695.

Harlow, E. and D. Lane. 1988. Antibodies: A laboratory manual. Cold Spring Harbor Laboratory, Cold Spring Harbor, New York.

Hazama, M., A. Aono, N. Ueno, and Y. Fujisawa. 1995. Efficient expression of a heterodimer of bone morphogenetic protein subunits using a baculovirus expression system. Biochem. Biophys. Res. Comm. 209: 859-866.

Hemmati-Brivanlou, A. and D.A. Melton. 1992. A truncated activin receptor inhibits mesoderm induction and formation of axial structures in Xenopus embryos. Nature 359: 609614.

- 1994. Inhibition of activin receptor signaling promotes neuralization in Xenopus. Cell 77: 273-281.

Hemmati-Brivanlou, A., O.G. Kelly, and D.A. Melton. 1994. Follistatin, an antagonist of activin, is expressed in the Spemann organizer and displays direct neuralizing activity. Cell 77: 283-295.

Holley, S.A., P.D. Jackson, Y. Sasai, B. Lu, E.M. DeRobertis, F.M. Hoffmann, and E.L. Ferguson. 1995. A conserved system for dorsal-ventral patterning in insects and vertebrates involving sog and chordin. Nature 376: 249-253.

Holtfreter, J. 1933. Die totale Exogastrulation, eine Selbstablösung des Ektoderms vom Entomesoderm. Roux's Arch. Entwicklungsmech. Org. 129: 669-793.

Jones, C.M., K.M. Lyons, P.M. Lapan, C.V.E. Wright, and B.L.M. Hogan. 1992. DVR-4 (bone morphogenetic protein-4) as a posterior-ventralizing factor in Xenopus mesoderm induction. Development 115: 639-647.

Kintner, C.R. and D.A. Melton. 1987. Expression of Xenopus N-CAM RNA in ectoderm is an early response to neural induction. Development 99: 311-325.

Kogawa, K., T. Nakamura, K. Sugino, K. Takio, K. Titani, and H. Sugino. 1991. Activin-binding protein is present in pituitary. Endocrinology 128: 1434-1440.

Kondo, M., K. Tashiro, G. Fujii, M. Asano, R. Miyoshi, R. Yamada, M. Muramatsu, and K. Shiokawa. 1991. Activin receptor mRNA is expressed early in Xenopus embryogenesis and the level of the expression affects the body axis formation. Biochem. Biophys. Res. Commun. 181: 684-690.

Krieg, P.A. and D.A. Melton. 1984. Functional messenger RNAs are produced by SP6 in vitro transcription of cloned cDNAs. Nucleic Acids Res. 12: 7057-7070.

Lamb, T.M., A.K. Knecht, W.C. Smith, S.E. Stachel, A.N. Economides, N. Stahl, G.D. Yancopolous, and R.M. Harland. 1993. Neural induction by the secreted polypeptide noggin. Science 262: 713-718.

Letsou, A., K. Arora, J.L. Wrana, K. Simin, V. Twombly, J. Jamal, K. Staehling-Hampton, F.M. Hoffmann, W.M. Gelbart, J. Massague, and M.B. O'Connor. 1995. Drosophila dpp signaling is mediated by the punt gene product: A dual ligandbinding type II receptor of the TGF $\beta$ receptor family. Cell 80: 899-908.

Lopez, A.R., J. Cook, P.L. Deininger, and R. Derynck. 1992. Dominant-negative mutants of transforming growth factor$\beta 1$ inhibit the secretion of different transforming growth factor- $\beta$ isoforms. Mol. Cell. Biol. 12: 1674-1679.

Lyons, K.M., B.L.M. Hogan, and E.J. Robertson. 1995. Colocalization of BMP7 and BMP2 RNAs suggests that these factors cooperatively mediate tissue interactions during murine development. Mech. Dev. 50: 71-83.

Maeno, M., Y. Xue, T.I. Wood, R.C. Ong, and H.F. Kung. 1993. Cloning and expression of cDNA encoding Xenopus laevis bone morphogenetic protein-1 during early embryonic development. Gene 134: 257-261.

Mangold, O. 1933. Uber die Induktionsfähigkeit der verschiede- 
nen Bezirke der Neurula von Urodelen. Naturwissenschaften 43: 761-766.

Massagué, J. 1992. Receptors for the TGF- $\beta$ family. Cell 69: $1067-1070$.

Matzuk, M.M., T.R. Kumar, and A. Bradley. 1995a. Different phenotypes for mice deficient in either activins or activin receptor type II. Nature 374: 356-360.

Matzuk, M.M., T.R. Kumar, A. Vassalli, J.R. Bickenbach, D.R. Roop, R. Jaenisch, and A. Bradley. 1995b. Functional analysis of activins during mammalian development. Nature 374: 354-356.

Melton, D.A., P.A. Krieg, M.R. Rebagliati, T. Maniatis, K. Zinn, and M.R. Green. 1984. Efficient in vitro synthesis of biologically active RNA and RNA hybridization probes from plasmids containing a bacteriophage SP6 promoter. Nucleic Acids Res. 12: 7035-7056.

Nieuwkoop, P.D. 1952. Activation and organization of the central nervous system in amphibians. J. Exp. Zool. 120: 83108.

- 1985. Inductive interactions in early amphibian development and their general nature. I. Embryol. Exper. Morphol. (Suppl.) 89: 333-347.

Nieuwkoop, P.D. and J. Faber. 1967. Normal table of Xenopus laevis. Garland Publishing, Amsterdam, North Holland.

Nishimatsu, S., S. Oda, K. Murakami, and N. Ueno. 1992a. Multiple genes for Xenopus activin receptor expressed during early embryogenesis. FEBS Lett. 303: 81-84.

Nishimatsu, S., A. Suzuki, A. Shoda, K. Murakami, and N. Ueno. 1992b. Genes for bone morphogenetic proteins are differentially transcribed in early amphibian embryos. Biochem. Biophys. Res. Commun. 186: 1487-1495.

Ozkaynak, E., D.C. Rueger, E.A. Drier, C. Corbett, R.J. Ridge, T.K. Sampath, and H. Oppermann. 1990. OP-1 cDNA encodes an osteogenic protein in the TGF- $\beta$ family. EMBO $I$. 9: 2085-2093.

Padgett, R.W., J.M. Wozney, and W.M. Gelbart. 1993. Human BMP sequences can confer normal dorsal-ventral patterning in the Drosophila embryo. Proc. Natl. Acad. Sci. 90: 29052909.

Panganiban, G.E.F., K.E. Rashka, M.D. Neitzel, and M. Hoffmann. 1990. Biochemical characterization of the Drosophila $d p p$ protein, a member of the transforming growth factor $\beta$ family of growth factors. Mol. Cell. Biol. 10: 2669-2677.

Pannese, M., C. Polo, M. Andreazzoli, R. Vignali, B. Kablar, G. Barsacchi, and E. Boncinelli. 1995. The Xenopus homologue of Otx2 is a maternal homeobox gene that demarcates and specifies anterior body regions. Development 121: 707-720.

Ruberte, E., T. Marty, D. Nellen, M. Affolter, and K. Basler. 1995. An absolute requirement for both the type II and type I receptors, punt and thick veins, for dpp signaling in vivo. Cell 80: 889-897.

Sasai, Y., B. Lu, H. Steinbeisser, and E.M. DeRobertis. 1995. Regulation of neural induction by the Chd and BMP-4 antagonistic patterning signals in Xenopus. Nature 376: 333336.

Schmidt, J.E., A. Suzuki, N. Ueno, and D. Kimelman. 1995. Localized BMP-4 mediates dorsal/ventral patterning in the early Xenopus embryo. Dev. Biol. 169: 37-50.

Schulte-Merker, S., J.C. Smith, and L. Dale. 1994. Effects of truncated activin and FGF receptors and of follistatin on the inducing activities of $\mathrm{BVgl}$ and activin: Does activin play a role in mesoderm induction? EMBO J. 13: 3533-3541.

Shimell, M.J., E.L. Ferguson, S.R. Childs, and M.B. O'Connor. 1991. The Drosophila dorsal-ventral patterning gene tolloid is related to human bone morphogenetic protein 1 . Cell 67: $469-481$.
Sive, H.L., K. Hattori, and H. Weintraub. 1989. Progressive determination during formation of the anteroposterior axis in Xenopus laevis. Cell 58: 171-180.

Suzuki, A., R.S. Thies, N. Yamaji, I.J. Song, J.M. Wozney, K. Murakami, and N. Ueno. 1994. A truncated bone morphogenetic protein receptor affects dorsal-ventral patterning in the early Xenopus embryo. Proc. Natl. Acad. Sci. 91: 1025510259.

tenDijke, P., H. Yamashita, H. Ichijo, P. Franzen, M. Laiho, K. Miyazono, and C.H. Heldin. 1994. Characterization of type I receptors for transforming growth factor $-\beta$ and activin. Science 264: 101-104.

Thomsen, G., T. Woolf, M. Whitman, S. Sokol, J. Vaughan, W. Vale, and D.A. Melton. 1990. Activins are expressed early in Xenopus embryogenesis and can induce axial mesoderm and anterior structures. Cell 63: 485-493.

Vale, W., A. Hsueh, C. Rivier, and J. Yu. 1990. The inhibin/ activin family of hormones and growth factors. In Peptide growth factors and their receptors (ed. M.B. Sprorn and A. B. Roberts), pp. 211-248. Springer-Verlag, Berlin, Germany.

Wilson, P.A. and A. Hemmati-Brivanlou. 1995. Induction of epidermis and inhibition of neural fate by BMP-4. Nature 376: 331-333.

Wilson, P.A. and D.A. Melton. 1994. Mesodermal patterning by an inducer gradient depends on secondary cell-cell communication. Curr. Biol. 4: 676-686.

Wittbrodt, J. and F.M. Rosa. 1994. Disruption of mesoderm and axis formation in fish by ectopic expression of activin variants: The role of maternal activin. Genes $\&$ Dev. 8: 14481462.

Wozney, J.M., V. Rosen, A.J. Celeste, L.M. Mitsock, M.J. Whitters, R.W. Kriz, R.M. Hewick, and E.A. Wang. 1988. Novel regulators of bone formation: Molecular clones and activities. Science 242: 1528-1534.

Wrana, J.L., L. Attisano, R. Wieser, F. Ventura, and J. Massague. 1994. Mechanism of activation of the TGF- $\beta$ receptor. $\mathrm{Na}$ ture 370: 341-347.

Wright, C.V.E., E.A. Morita, D.J. Wilkin, and E.M. DeRobertis. 1990. The Xenopus XlHbox 6 homeo protein, a marker of posterior neural induction, is expressed in proliferating neurons. Development 109: 225-234.

Yamashita, H., P. tenDijke, D. Huylebroeck, T.K. Sampath, M. Andries, J.C. Smith, C.-H. Heldin, and K. Miyazono. 1995. Osteogenic protein-1 binds to activin type II receptors and induces certain activin-like effects. J. Cell Biol. 130: 217226. 


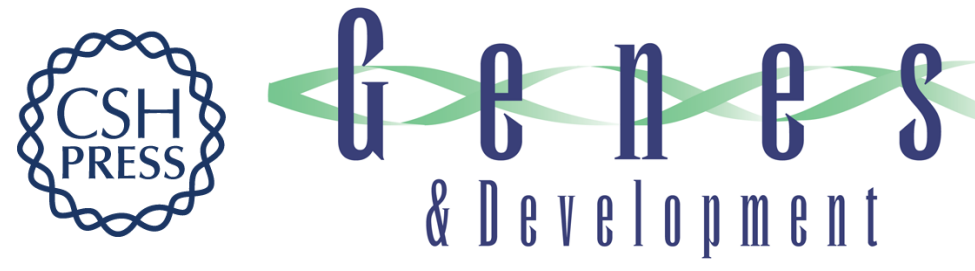

\section{Disruption of BMP signals in embryonic Xenopus ectoderm leads to direct neural induction.}

S H Hawley, K Wünnenberg-Stapleton, C Hashimoto, et al.

Genes Dev. 1995, 9:

Access the most recent version at doi:10.1101/gad.9.23.2923

References This article cites 64 articles, 21 of which can be accessed free at:

http://genesdev.cshlp.org/content/9/23/2923.full.html\#ref-list-1

License

Email Alerting

Service

Receive free email alerts when new articles cite this article - sign up in the box at the top right corner of the article or click here.

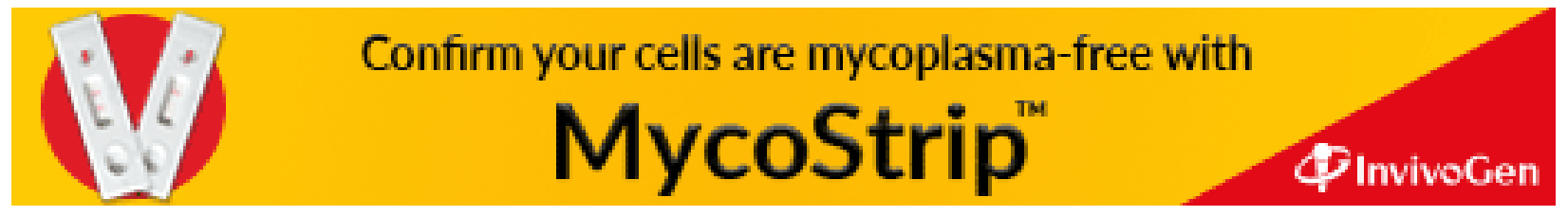

